\title{
PENGARUH PENAMBAHAN LIMBAH AMPAS TAHU \\ PADA FESES SAPI TERHADAP PRODUKSI METAN, KECERNAAN BAHAN ORGANIK DAN pH \\ The Effect Of Co-Digestion Of Dairy Cow Feces With Tofu Cake On Methan \\ Production, Volatile Solid Reduction And Ph Value
}

\author{
Andika Adji Prasetya ${ }^{1}$, Sutaryo $^{2}$, Agung Purnomoadi ${ }^{3}$ \\ 1) Mahasiswa Fakultas Peternakan dan Pertanian Universitas Diponegoro, \\ diekadrop4@gmail.com \\ 2) Dosen Pembimbing Biogas Fakutas Peternakan dan Pertanian Universitas Diponegoro \\ ${ }^{3)}$ Dosen Pembimbing Biogas Fakultas Peternakan dan Pertanian Universitas Diponegoro
}

\begin{abstract}
ABSTRAK
Tujuan dari penelitian ini adalah untuk mengetahui pengaruh penggunaan limbah ampas tahu pada feses sapi terhadap produksi metan, kecernaan bahan organik dan nilai pH. Perlakuan yang diterapkan yaitu T0 dengan bahan isian $100 \%$ feses sapi peranakan fries holstein (PFH) ditambah air (1:1) dan T1 dengan bahan isian $95 \%$ feses sapi PFH dan $5 \%$ limbah ampas tahu kemudian diencerkan dalam air (1:1). Ulangan yang dilakukan adalah dengan pengambilan data sebanyak 3 kali Hydraulic retention time (HRT), dimana satu kali HRT sama dengan 25 hari. Hasil dari penelitian ini adalah tidak ada pengaruh yang nyata $(\mathrm{P}>0,05)$ dari perlakuan yang diterapkan terhadap produksi metan, kecernaan bahan organik dan nilai $\mathrm{pH}$. Tidak berpengaruhnya perlakuan penambahan ampas tahu terhadap produksi metan dikarenakan penambahan $\mathrm{C} / \mathrm{N}$ hanya sebesar 1,72 dari selisih ratio T0 dengan $\mathrm{T} 1$. Nilai $\mathrm{pH}$ pada masing-masing digester berada pada kisaran nilai $\mathrm{pH}$ yang baik untuk pertumbuhan mikroorganisme anaerobik dalam menghasilkan biogas. Penambahan ampas tahu pada substrat biogas pada taraf 5\% pada feses sapi perah diperoleh hasil produksi gas metan, kecernaan bahan organik, dan $\mathrm{pH}$ slurry yang tidak berbeda nyata dari kedua digester.
\end{abstract}

Kata kunci : Limbah Ampas Tahu, Biogas, Feses Sapi, Gas Metan, Kecernaan Bahan Organik, $\mathrm{pH}$

\section{ABSTRACT}

The purpose of this research was to evalute the effect of co-digestion of dairy cow feces with tofu cake on methane production, volatile solid reduction and $\mathrm{pH}$. The applied treatments were T0 : 100\% dairy cow feces and tap water (1:1) and T1 : 95\% dairy cow feces and 5\% tofu cake then diluted with tap water (1:1). The data was colletcted for three times hydraulic retention time (HRT), where a HRT was equals to 25 days. The results of this study showed that there were no significant effect $(P>0.05)$ of treatments on methan production, volatile solid reduction and $\mathrm{pH}$ value. No effect of tofu cake addition due to the addition of $\mathrm{C} / \mathrm{N}$ is only 1.72 from the difference of ratio $\mathrm{TO}$ with $\mathrm{Tl}$. The $\mathrm{pH}$ value of each digester was in the range of $\mathrm{pH}$ values that appropriate for the growth of anaerobic microorganisms. The addition of 5\% tofu cake to dairy cow feces obtained methane production, volatile solid reduction and $\mathrm{pH}$ slurry which were not significantly different $(P>0.05)$ compare to control digester.

Keywords: Tofu Cake, Biogas, Dairy Cow Feces, Methane Production, Volatile Solid Reduction, $\mathrm{pH}$ 


\section{PENDAHULUAN}

Masyarakat pedesaan sebagian besar berprofesi sebagai peternak atau petani yang memelihara ternak baik ruminansia maupun non ruminansia. Ternak ruminansia maupun non ruminasia dipelihara untuk diambil hasil produksinya yang berupa daging, susu, telur, maupun dipelihara untuk diambil anaknya atau keturunannya. Selain produk utama, ternak juga menghasilkan produk sampingan berupa feses dan urin. Jika feses dan urin tidak dimanfaatkan atau dikelola maka akan mencemari lingkungan. Oleh karena itu, perlu adanya penanganan limbah ternak yang sebelumnya mencemari lingkungan, akhirnya dapat dimanfaatkan oleh masyarakat.

Pengolahan limbah peternakan untuk mengurangi pencemaran lingkungan salah satunya melalui produksi biogas. Produksi biogas dari feses ternak memberikan keuntungan finansial karena memiliki nilai jual. Biogas dihasilkan dari feses ternak yang difermentasi oleh bakteri metanogenik secara anaerob.

Salah satu faktor utama untuk menghasilkan gas metan yaitu rasio $\mathrm{C} / \mathrm{N}$. Jika rasio $\mathrm{C} / \mathrm{N}$ terlalu tinggi, maka nitrogen akan terkonsumsi sangat cepat oleh bakteribakteri metanogen untuk memenuhi kebutuhan protein dan tidak akan lagi bereaksi dengan sisa karbonnya, sehingga hasil produksi gas metana rendah. Di lain pihak, jika rasio $\mathrm{C} / \mathrm{N}$ sangat rendah, nitrogen akan dibebaskan dan terkumpul dalam bentuk $\mathrm{NH}_{4} \mathrm{OH}$. Rentang rasio $\mathrm{C} / \mathrm{N}$ antara 25-30 merupakan rentang optimum untuk proses penguraian anaerob (Hartono, 2009). Feses sapi mengandung hemisellulosa sebesar 18,6\%; sellulosa $25,2 \%$; lignin 20,2\%; nitrogen $1,67 \%$; fosfat $1,11 \%$ dan kalium sebesar $0,56 \%$ (Sihotang, 2010). Feses sapi PFH mempunyai $\mathrm{C} / \mathrm{N}$ ratio sebesar 16,6-25\% (Siallagan, 2010). Oleh karena itu perlu ditambahkan bahan lain untuk meningkatkan suplemen substrat biogas yang berguna untuk mengoptimalkan kinerja bakteri untuk meningkatkan produksi gas metan. Salah satu bahan penunjang $\mathrm{C} / \mathrm{N}$ untuk feses sapi sebagai substrat biogas, yaitu limbah ampas tahu. Limbah ampas tahu masih mempunyai kandungan nutrisi yang dapat dimanfaatkan dengan baik, salah satunya untuk menambah rasio $\mathrm{C} / \mathrm{N}$ pada bahan isian biogas. Limbah ampas tahu mempunyai kandungan air 82,69\%; abu 0,55\%; lemak $0,62 \%$; protein $2,42 \%$ dan karbohidrat 13,71\% (Widarti et al., 2012).

Tujuan dari penelitian ini adalah untuk mengetahui pengaruh penggunaan limbah ampas tahu pada pembuatan biogas dari feses sapi Peranakan Frisian Holstein (PFH) terhadap produksi metan, kecernaan bahan organik dan $\mathrm{pH}$. Manfaat dari penelitian ini adalah dapat memberikan dampak positif bagi lingkungan dan dapat menghasilkan biogas yang optimal.

\section{METODOLOGI}

Metode penelitian yang digunakan dalam penelitian ini meliputi rancangan pengujian variabel dan analisa data. Tahap prosedur penelitian meliputi penyiapan materi, adaptasi, dan pelaksanaan penelitian. Penelitian utama dilakukan dengan digester tersebut diisi secara kontinyu yang dilakukan setiap hari. Slurry dikeluarkan dari digester sesuai dengan banyaknya substrat baik itu substrat feses campur air (T0) maupun substrat feses campur ampas tahu (T1) yang dimasukkan dalam digester yaitu $224 \mathrm{~g}$. Variabel yang diamati pada penelitian ini meliputi produksi metan yang diukur setiap hari, kecernaan bahan organik dari substrat yang 
diukur seminggu sekali dan $\mathrm{pH}$ yang diukur dua minggu sekali. Data yang diperoleh dianalisis dengan Uji Beda t-test menggunakan aplikasi SPSS.Hipotesis yang digunakan dalam penelitian sesuai dengan Sudjana (2005) yaitu: $\mathrm{H}_{0}: \mu_{1}=\mu_{2}$, artinya tidak terdapat perbedaan yang nyata terhadap produksi metan, $\mathrm{pH}$ dan kecernaan bahan organik substrat berdasarkan perlakuan penambahan limbah ampas tahu dengan tanpa penambahan limbah ampas tahu.

Materi yang digunakan pada penelitian ini adalah feses sapi PFH yang didapat dari kandang sapi perah di Fakultas Peternakan dan Pertanian Universitas Diponegoro. Ampas tahu didapat dari industri rumah tangga Jl. Tandang Raya, Kelurahan Jomblang, Kecamatan Candisari,
Semarang, Jawa Tengah, air sebagai bahan pelarut feses, dan larutan $\mathrm{NaOH} 4 \%$. Alat yang digunakan adalah 2 buah rangkaian digester yang terdiri dari tabung pencerna stainless dengan kapasitas $7000 \mathrm{ml}$, karet penutup, botol kaca, selang teflon, malam dan tedlar gas bag. Alat pengukur metan terdiri dari pompa air, gelas ukur kapasitas $1000 \mathrm{ml}$, rangkaian kayu untuk menopang gelas ukur, selang karet, pompa air dan bak penampung air sedangkan alat lain yang digunakan yaitu timbangan digital berjenis Electronic Price Computing Scale kapasitas $30 \mathrm{~kg}$ dengan ketelitian $1 \mathrm{~g}$, timbangan analitik, corong, sendok, keran plastik, gelas beker, freezer, refrigerator, tanur dan oven.Model digester tipe continous feeding yang digunakan disajikan dalam Ilustrasi 1.

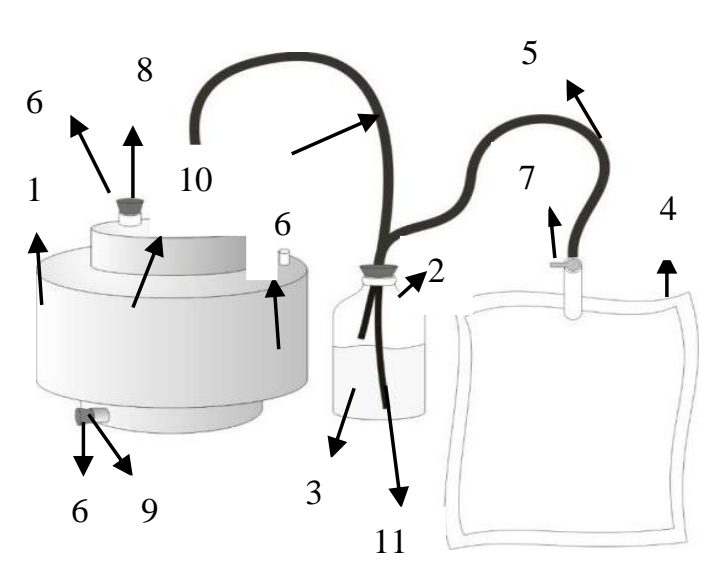

Keterangan:

1. Tabung pencerna

2. Botol Kaca

3. Larutan $\mathrm{NaOH} 4 \%$

4. Tedlar gas bag

5. Selang teflon

6. Karet penutup

7. Keran plastik

8. Lubang pemasukan substrat

9. Lubang pengeluaran slurry

10. Lubang pengeluaran gas

11. Selang dari digester tercelup ke dalam larutan

Ilustrasi 1. Model Digester Tipe Continous Feeding

\section{HASIL PENELITIAN \\ PEMBAHASAN \\ 1. Pengaruh Penambahan Limbah Ampas Tahu pada Feses Sapi PFH terhadap Produksi Metan}

Hasil analisis statistik menunjukkan bahwa tidak ada perbedaan yang nyata $(\mathrm{P}>0,05)$ antar perlakuan yang artinya substitusi limbah ampas tahu sebesar 5\% dari substrat feses sapi perah tidak berpengaruh terhadap produksi gas metan yang dihasilkan. Tidak berpengaruhnya perlakuan penambahan ampas tahu dikarenakan penambahan $\mathrm{C} / \mathrm{N}$ hanya sebesar 1,72 dari selisih ratio $\mathrm{T} 0$ dengan T1. Data hasil uji $\mathrm{C} / \mathrm{N}$ digester dengan bahan isian T0 memiliki nilai 16,76 dan digester dengan isian $\mathrm{T} 1$ memiliki nilai 18,48. Menurut Hartono (2009) rentang rasio $\mathrm{C} / \mathrm{N}$ antara 25-30 merupakan rentang 
optimum untuk proses penguraian anaerob. Jika rasio $\mathrm{C} / \mathrm{N}$ terlalu tinggi, maka nitrogen akan terkonsumsi sangat cepat oleh bakteribakteri metanogen untuk memenuhi kebutuhan protein dan tidak akan lagi bereaksi dengan sisa karbonnya. Sebagai hasilnya produksi gas akan rendah. Di lain pihak, jika rasio $\mathrm{C} / \mathrm{N}$ sangat rendah, nitrogen akan dibebaskan dan terkumpul dalam bentuk $\mathrm{NH}_{4} \mathrm{OH}$. Parameter $\mathrm{C} / \mathrm{N}$ bukan faktor satu-satunya yang mengakibatkan produksi gas metan dalam digester tersebut menghasilkan gas yang tinggi atau rendah karena masih terdapat beberapa parameter atau faktor lain yang harus diperhatikan seperti bahan baku isian, derajat keasaman dan temperatur (Suyitno et al,. 2010).

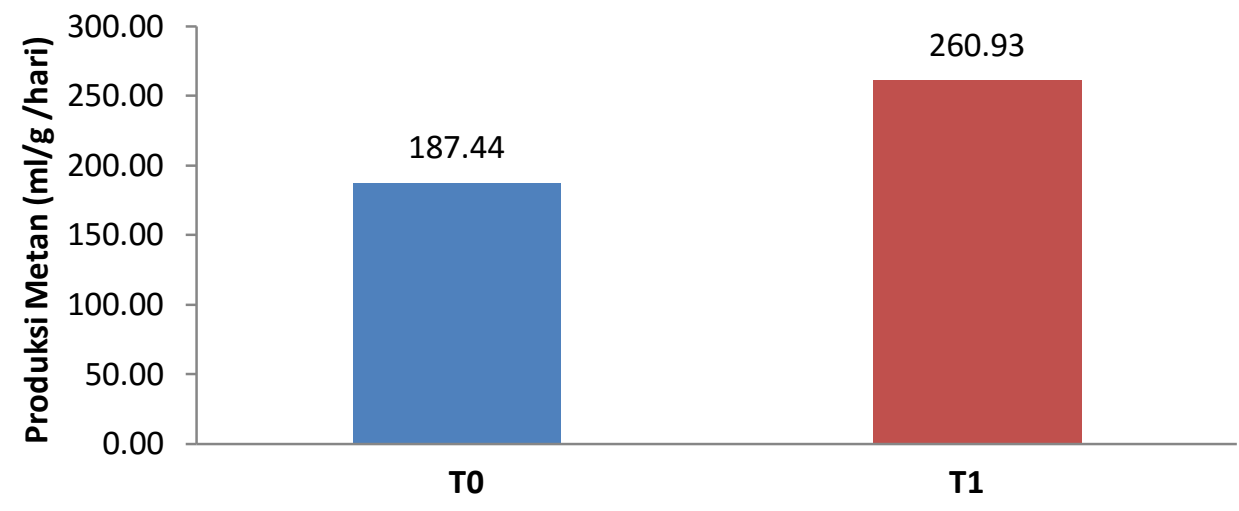

Ilustrasi 2. Rata-rata Produksi Metan Harian pada Feses Campur Air (T0) dan Feses Campur Ampas Tahu (T1) Selama 3 HRT

2. Pengaruh Penambahan Limbah Ampas Tahu pada Feses Sapi PFH terhadap Kecernaan Bahan Organik

Secara statistik menunjukkan tidak adanya perbedaan yang nyata $(\mathrm{P}>0,05)$ dari perlakuan penggunaan ampas tahu (T1) sebagai bahan tambahan feses terhadap produksi metan yang dihasilkan. Hal ini menunjukkan bahwa perbedaan bahan isian dan kandungan bahan organik pada bahan isian dari digester tidak mempengaruhi hasil produksi gas metan yang dihasilkan. Biogas dihasilkan dari bahan organik dengan bantuan bakteri metanogenik pada proses fermentasi secara anaerob. Perbedaan yang tidak nyata tersebut dimungkinkan karena standar deviasi yang terlalu tinggi akibat rentang nilai kecernaan yang fluktuatif. Nilai signifikansi berbanding terbalik dengan standar deviasi, jadi semakin besar standar deviasi akan menyebabkan semakin kecil peluang untuk mendapatkan hasil yang signifikan atau yang memberikan pengaruh. Bahan organik dari substrat yang dapat dicerna mikroorganisme atau didegradasi merupakan salah satu faktor penting penyebab tinggi rendahnya produksi metan yang dihasilkan (Abubakar dan Ismail, 2012). 


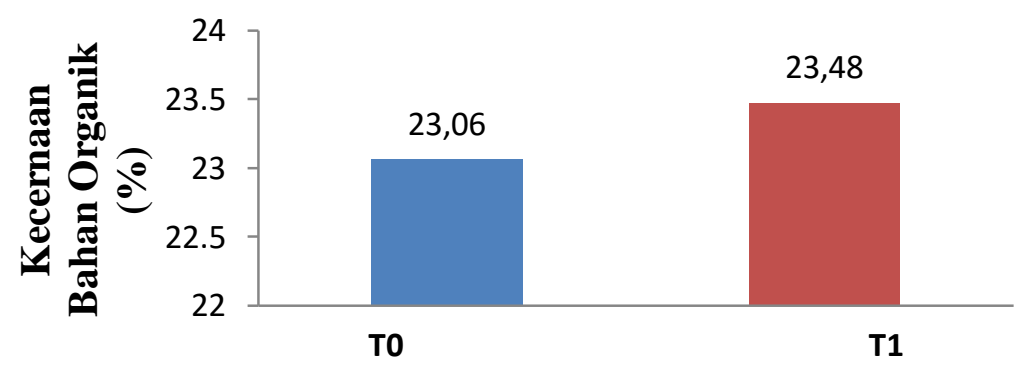

Ilustrasi 3. Rata-rata Kecernaan Bahan Organik pada Feses Campur Air (T0) dan Feses Campur Ampas Tahu (T1) Selama 3 HRT

Tinggi rendahnya kecernaan bahan organik mempunyai arti seberapa banyaknya bakteri yang dapat mendegradasi substrat di dalam digester untuk menghasilkan biogas. Semakin besar presentase kecernaan bahan organik, semakin banyak pula jumlah bahan organik dalam substrat yang dapat dicerna oleh bakteri dan semakin tinggi pula produksi metan yang dihasilkan. Penambahan limbah ampas tahu sebagai substrat menyebabkan bertambahnya kecernaan bahan organik, karena mikroorganisme mendapatkan tambahan nutrisi untuk menghasilkan biogas lebih banyak dibandingkan tanpa penambahan bahan organik. Hal ini sesuai dengan pendapat Bluman (2004), yang menyatakan bahwa semakin besar standar deviasi akan menyebabkan semakin kecil peluang untuk mendapatkan hasil signifikan.

\section{Pengaruh Penambahan Limbah Ampas Tahu terhadap pH Slurry}

Kondisi pH berpengaruh terhadap pertumbuhan dan aktivitas bakteri untuk mencerna bahan organik dalam substrat biogas sehingga akan menghasilkan gas metan. Menurut Syahputra (2009), bakteri yang terlibat dalam proses anaerobik membutuhkan beberapa elemen sesuai dengan kebutuhan organisme hidup seperti sumber makanan dan kondisi lingkungan yang optimum.

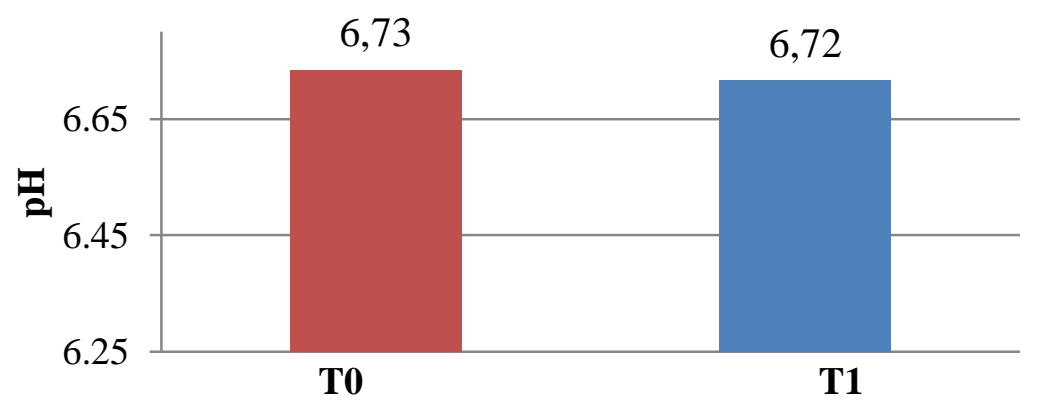

Ilustrasi 4. Nilai Rata-rata pH Slurry selama 11 minggu

Nilai pH slurry pada T0 dan T1 berkisar 6,72-6,73, artinya ketika $\mathrm{pH}$ slurry mengalami peningkatan sampai mendekati netral maka akan menyebabkan produksi metan meningkat. Sebaliknya, semakin rendah pH slurry sampai mendekati asam maka produksi metan yang dihasilkan akan menurun. Nilai $\mathrm{pH}$ yang dibutuhkan untuk digester adalah antara 6,2-8. (Amaru, 2004) sehingga ketika pH slurry mendekati 
kondisi netral, maka akan menghasilkan produksi yang tinggi, hal tersebut karena kondisi $\mathrm{pH}$ optimal sangat mendukung aktivitas bakteri untuk membentuk gas metan secara optimal.

\section{KESIMPULAN}

Berdasarkan penelitian yang dilakukan dapat disimpulkan bahwa penambahan limbah ampas tahu pada substrat biogas dengan bahan baku feses sapi perah diperoleh hasil produksi gas metan, kecernaan bahan organik, dan $\mathrm{pH}$ slurry yang tidak berbeda nyata dari kedua digester.Saran yang dapat diberikan pada kegiatan penelitian ini adalah perlu suhu ruangan yang signifikan agar suhu tidak berubah-ubah saat melakukan penelitian karena dapat mengubah hasil dari penelitian. Selain itu perlu diketahui juga seberapa persen penggunaan limbah ampas tahu dalam digester untuk menghasilkan biogas yang lebih optimal.

\section{DAFTAR PUSTAKA}

Abubakar, B.S.U.I. and N. Ismail. 2012. Anaerobic digestion cow dung for biogas production. Journal of Enginering and Applied Sciences. 7(2): 169-172.

Amaru, K..2004. Rancang Bangunan dan Uji Kinerja Biodigester Plastik. Polythilene Skala Kecil. Jurusan Teknologi Pertanian. Fakultas Pertanian. Universitas Padjajaran..

Bluman, A.G. 2004. Elementary Statistics: A step by Step Aproach Fiftth Edition. MCGraw Hill, New York.

Hartono, R. 2009. Produksi Biogas dari Jerami Padi dengan Penambahan Kotoran Kerbau. Seminar Nasional Teknik Kimia Indonesia - SNTKI
2009 ISBN 978-979-98300-1-2. Bandung, 19-20 Oktober 2009.

Siallagan, R. 2010. Pengaruh waktu tinggal dan komposisi bahan baku pada proses fermentasi limbah cair industri tahu terhadap produksi biogas. Fakultas Teknik Program Magister Teknik Kimia Universitas Sumatera Utara, Medan.

Sihotang, B. 2010. Kandungan Senyawa Kimia Pada Pupuk Kandang Berdasarkan Jenis Binatangnya. Avaliable at r.yuwie.com/blog/ entry. Accession date: 29 November 2010.

Suyitno, M. Nizam dan Dharmanto. 2010. Teknologi Biogas. Graha Ilmu. Surakarta.

Syahputra, A. 2009.Produksi Gas Bio dari Campuran Kotoran Sapi Perah dengan Kompos Jerami Padi pada Rasio C/N yang Berbeda. Fakultas Peternakan, Institut Pertanian Bogor, Bogor. (Skripsi Sarjana Peternakan).

Widiarti, B. N., S. Syamsiah dan P. Mulyono. 2012. Degradasi Substrat Volatile Solid Pada Produksi Biogas Dari Limbah Pembuatan Tahu Dan Kotoran Sapi.Jurnal Rekayasa Proses.Vol 6, No. 1, 2012. 